Goldschmidt 2021 Abstract

https://doi.org/10.7185/gold2021.5160

\section{Zircon as a recorder of chemical change during metamorphism of Neoarchean lower crust, Shevaroy Block, Eastern Dharwar Craton, southern India}

\author{
DANIEL E. HARLOV ${ }^{1}$, DANIEL DUNKLEY ${ }^{2}$, EDWARD \\ HANSEN $^{3}$, ISHWAR-KUMAR C ${ }^{4}$, VINOD SAMUEL ${ }^{5}$ AND \\ TOMOKAZU HOKADA ${ }^{6}$ \\ ${ }^{1}$ Deutsches GeoForschungsZentrum GFZ \\ ${ }^{2}$ Institute of Geophysics, Polish Academy of Sciences \\ ${ }^{3}$ Hope College \\ ${ }^{4}$ Indian Institute of Technology Kanpur \\ ${ }^{5}$ Yonsei University \\ ${ }^{6}$ National Institute of Polar Research \\ Presenting Author: dharlov@gfz-potsdam.de
}

Changes in whole-rock and mineral chemistry are seen along a $95 \mathrm{~km}$ traverse of late Archean granitoid orthogneisses in the Shevaroy Block, Eastern Dharwar Craton, southern India. These include whole-rock depletion of $\mathrm{Rb}, \mathrm{Cs}$, Th, and $\mathrm{U}$ in granulitegrade rocks relative to to amphibolite-grade rocks further north. Oxidation state ranges from low (below FMQ) in amphibolitegrade rocks to high (near $\mathrm{Mt}-\mathrm{Hm}$ ) in the granulites. REEs are hosted by titanite and allanite in amphibolite-grade rocks, by monazite in the region of the orthopyroxene-in isograd, and by fluorapatite in granulite-grade charnockite.

Sub-grain imaging and SIMS analysis of zircon from 29 samples of dioritic, tonalitic, and granitic orthogneiss from the traverse reveals magmatic zircon cores that record the emplacement of the granitoid protoliths mostly about 2580-2550 Ma, along with mid to late Archean tonalites. Protolith zircon was modified during metamorphism by overgrowth and/or replacement. Uranium-enriched metamorphic zircon, dominant in the amphibolite-grade gneisses, formed at ca. $2530 \mathrm{Ma}$, predating retrograde titanite growth at ca. 2500 Ma. Uraniumdepleted mantles grew on zircon between 2530 and $2500 \mathrm{Ma}$ in granulite-grade samples south of the orthopyroxene-in isograd. In some of these samples, the depleted metamorphic zircon is preceeded by mantles of U-undepleted zircon, indicating a progression of metamorphic zircon growth with increasing depleted compositions between ca. 2540 and $2500 \mathrm{Ma}$.

In the absence of monazite or other actinide-bearing accessory minerals, with increasing metamorphic grade and oxidation state, zircon became depleted in U, Th, Y, and HREE. Whole-rock UTh-Zr compositions became decoupled from relict magmatic zircon compositions, reflecting the development of U-depleted magmatic zircon and indicating that bulk chemical differences along the traverse were produced during metamorphism, rather than just reflecting differences in the dioritic to granitic protoliths. Although in situ anatexis and melt extraction may have played a role, whole rock and zircon trace element depletion can be explained by the action of externally-derived, oxidizing, low $-\mathrm{H}_{2} \mathrm{O}$ activity saline fluids migrating up through the mid to lower crust during subduction related processes related to the collision and concatenation of island arcs and continental blocks that assembled the Dharwar Craton at the end of the Archean. 